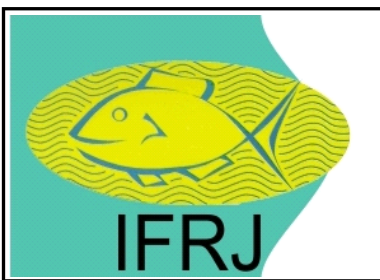

Available online at: http://ejournal-balitbang.kkp.go.id/index.php/ifrj

e-mail:ifrj.puslitbangkan@gmail.com

INDONESIAN FISHERIES RESEARCH JOURNAL

Volume 22 Number 1 June 2016

p-ISSN: 0853-8980

e-ISSN: 2502-6569

Accreditation Number: 704/AU3/P2MI-LIPI/10/2015

\title{
STATUS OF SMALL PELAGIC FISHERY IN THE MAKASSAR STRAIT BASED AT THE NORTHERN PART OF JAVA
}

\author{
Sri Turni Hartati ${ }^{\star 1}$, Setiya Triharyuni ${ }^{1}$, and Lilis Sadiyah ${ }^{1}$ \\ Center for Fisheries Research and Develompment, Jln. Pasir Putih II, Ancol Timur, Jakarta Utara, 14430, Indonesia \\ Received; Sept 21-2015 Received in revised from March 29-2016; Accepted April 01-2016
}

\begin{abstract}
The coastal of Makassar Strait is one of main fishing grounds for purse seine vessels from northern part of Java which based at the following landing sites, i.e. Pekalongan, Tegal and Juwana. The purse seine fishery predominantly targets small pelagic fish. This paper attempts to present the current condition of small pelagic fishery in the Makassar Strait. Catch and effort (trip) data between 2004 and 2011 from the three landing sites were used to estimate Maximum Sustainable Yield (MSY) using Schaefer \& Fox models. The results showed a decreasing trend in the catch rate, from 30.83 tons/trip in 2004 to 12.27 tons/trip in 2011. The estimated MSY is at the range of 34,70537,930 tons with optimum efforts for $2,234-2,500$ purse seine trips. Thus the level of purse seine fishing effort in 2011 , i.e. 3,078 trips, was exceeding the optimum effort. The decreasing trend in the catch rate may indicate overfishing is occurring between 2004 and 2011. For management of the small pelagic fisheries in the waters of Makassar Strait, important action recommended is fishing effort restrictions. The effort allowed would be only in the range of 2,234-2,500 purse seine trips, and the fishing capacity needs to be controled.
\end{abstract}

Keywords: Purse seine fisheries; Makassar Strait; Northern Java

\section{INTRODUCTION}

The Indonesian marine waters for fisheries management are divided into 11 Fisheries Management Areas (FMAs), i.e. FMAs 571, 572, $573,711,712,713,714,715,716,717$ and 718 (Ministrial regulation of Marine Affair and Fisheries No. PER. 01/MEN/2009 on Indonesian Fisheres Management Areas). There are some management issues due to, for example, open access fisheries which have spurred the fishing pressure that exceeds carrying capacity of the existing resources. Several efforts to increase the catchability by the Indonesian fishing vessels included the use of larger size of vessels, more effective fishing gear and the use of fishing devices (Cardinale et al., 2009; Purwanto, 2011), so that the fishing effort continue to increase. Overfishing that, inter alia, caused by modern fishing technology is considered as a result of the fisheries crisis (Atmaja et al., 2011). Use of advanced technologies in the fishing fleet has rapidly increased beyond the level of sustainable catches. In the last couple of years, the commercial fleet has improved, fishing gear becomes more sophisticated and efficient, but fisheries management system is not in line with these changes, as well as the omission of the catch level exceeding the fish resources to rebuild (Fujita, 2008).

Makassar strait, located between Kalimantan and Celebes islands, is under FMA 713. Its coastal area is one of the main fishing grounds for purseiners from Northern Java mainly central Java (Potier \& Sadhotomo, 2003), i.e. based at Pekalongan, Tegal and Juana, where as its oceanic area is a fishing ground for artisanal fisheries from Celebes (Suwarso et al., 2012). The catch of purse seine fishery are dominantly by small pelagic fish, which is one of economic important comodities in the Makassar strait (Suwarso et al., 2012). The purse seine fishery has grown rapidly since the prohibition of trawl fishery in 1980 and started to extend their fishing grounds to the Makassar strait since 1986 (Potier \& Sadhotomo, 2003). The purse seine vessels normally spend between 53-84 days at sea. In fact, both economic and biological overfishing are occurring in the purse seine fishery from the Northern Java (Atmaja, 2011). This paper presents current status of the small pelagic fishery based in Java (Pekalongan, Juwana, and Tegal) fishing in the Makassar Strait and its management, and attempts 
to provide an input to the sustainable small pelagic fisheries management.

\section{MATERIALS AND METHODS}

Data and information such as the number of vessels, catch, catch composition, fishing areas, and purse seine catch rates as an indicator of stock abundance, obtained from the Tegal Coastal Fishing Port, Bajomulyo 1 Juwana Fishing Port and Pekalongan Nusantara Fishing Port (Figure 1).

Data catch and effort (trip) between 2004 and 2011 from the three landing sites were used to estimate MSY. Analysis of the data to estimate MSY done using surplus production models, i.e. Schaefer and Fox models (Pauly, 1984; Fox, 1970). According to Schaefer's model that catch per unit effort (U) and fishing effort $(E)$ have a linear negative, i.e:
$U=a-b \cdot E$

with optimum effort $\left(\mathrm{E}_{\mathrm{opt}}\right)$ and catch $\left(\mathrm{C}_{\mathrm{opt}}\right)$ calculated by equation:

$E_{\text {opt }}=\frac{a}{2 b} \operatorname{dan} C_{\text {opt }}=\frac{a^{2}}{4 b}$

Meanwhile, Fox's model stating that the catch per trip effort $(U)$ and fishing effort $(E)$ has an exponential relationship, yaitu:

$$
\begin{aligned}
& U=e^{c-d . E} \ldots \ldots \ldots \ldots \ldots \ldots \ldots \ldots \ldots \ldots \ldots \\
& E_{\text {opt }}=\frac{1}{d} \operatorname{dan} C_{\text {opt }}=\frac{1}{d} e^{(c-1)}
\end{aligned}
$$

where,

$$
\begin{array}{lll}
\mathrm{U} & : & \text { catch per unit effort } \\
\mathrm{E} & : & \text { Fishing effort (trip of purse seine) }
\end{array}
$$

a,b, c and d: constants.

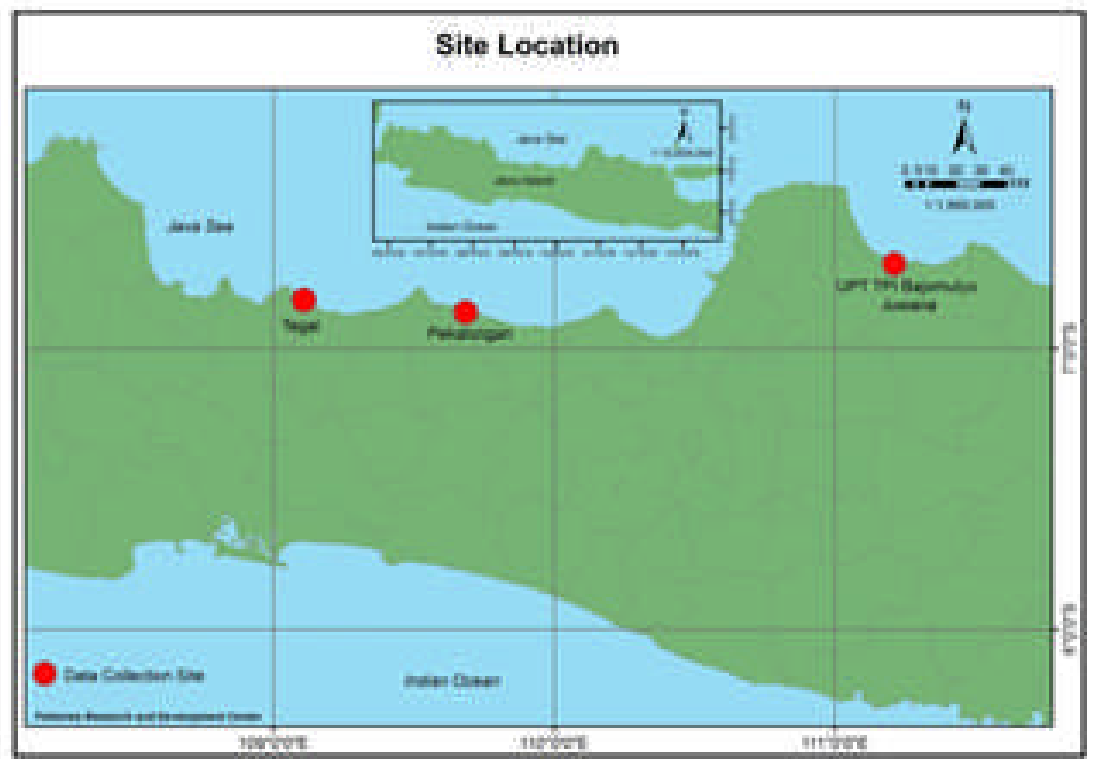

Figure 1. Location of the study sites.

\section{RESULTS AND DISCUSSION \\ Results}

\section{Operation Area of the Purse Seine}

The Makassar Strait has two types of habitat, i.e. coastal and oceanic (Figure 2). The coastal waters are the fishing ground for purse seiner from Java based at Pekalongan, Tegal and Juwana. The oceanic waters is the fishing ground for small scale fisheries from Sulawesi, such as small purse seine and payang. Fishing ground for purse seiners from Java in the coastal waters has commenced since early 1986. Most of the catches were brought to Java, and few of them were landed in Balikpapan (PPI Kampung Baru Tengah) and Samarinda (PPI Selili) using carrier vessels. 


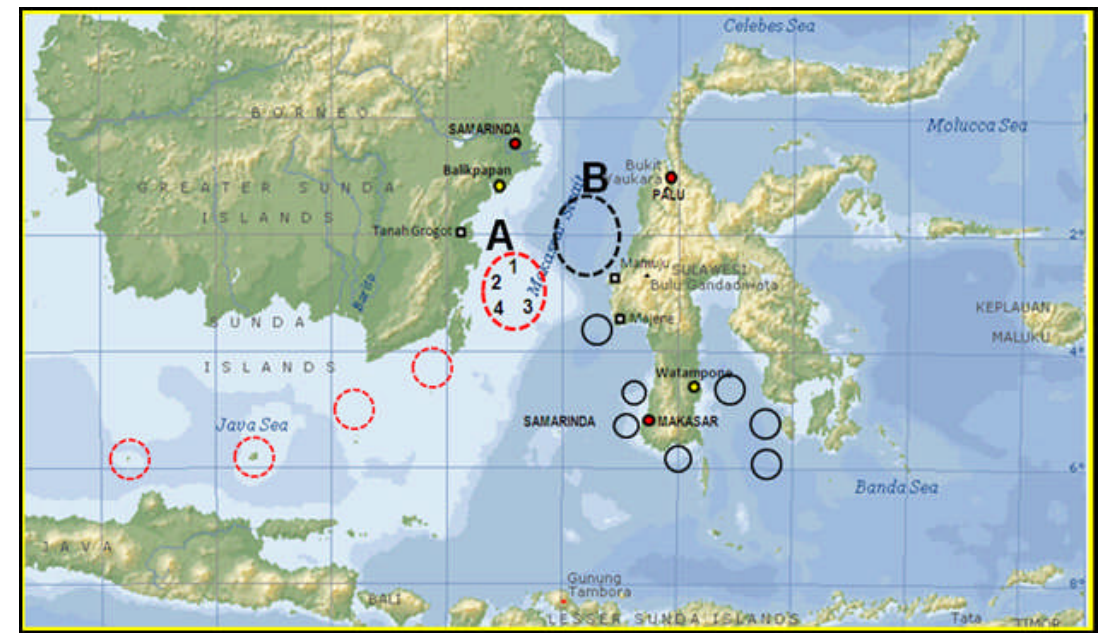

Note: 1- Balag-balagan; 2- Lumu-lumu, 3- Lari-larian; 4- Samber Gelap

Source: Hartati et al., 2012

Figure 2. Fishing ground of Java purse seiner perikanan PS Jawa (red cicle) and Mini Purse Seine of Celebes (black circle).

The fishing grounds for small pelagic are located in the southeast of Balikpapan, around the Sambar Gelap, Lumu-Lumu, Lari-Larian, and Balag-Balagan islands. According to Suwarso et al. (2012), the main small pelagic fish species caught by purse seine are Decapturus russeliand D. macrosoma. Other pelagic fish species is Rastrelliger Kanagurta, Amblygaster sirm, Selar Crumenophtalmus and Sardinella Gibbosa.

\section{Purse Seine Vessels Based at Pekalongan Nusantara Fishing Port}

In 2004, there were 252 active purse seine vessels (about $70 \%$ of the total registered vessels) operating in the Makassar Strait from Pekalongan Nusantara
Fishing Port (PPN Pekalongan). The number of active vessels decreased after 2003, as well as for the fishing area in the Java Sea and the South China Sea. In 2011 , the number of active vessels based at Pekalongan decreased to 104 vessels.

The catches from the Makassar Strait between 2004 and 2011 was estimated to be about $36 \%$ or an average of 9.47 tons. Java Sea contributes about 40 $\%$ or an average 9.95 tons, then South China Sea, Kangean Islands and other waters around $10 \%$ (2.39 tons), $10 \%$ (29.39 tons) and 4\% (2.55 tons), respectively. The percentage of purse seine operation by area based at Pekalongan from 2004-2011 is presented in Figure 3.

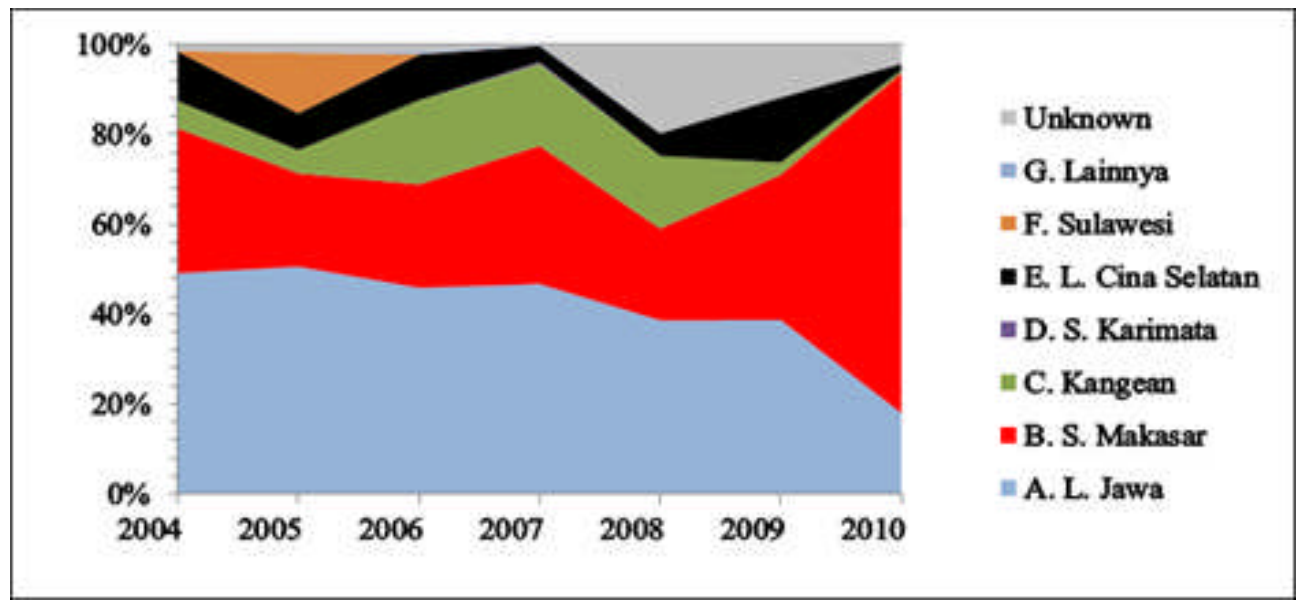

Figure 3. Percentage of purse seine operation by area based at Pekalongan in 2004-2011. 
There were decreasing trends in number of trips and catch rate between 2004 and 2011, this may indicate that the fisheries in Makassar Strait had collapsed (Figure 4). The CPUE increase in 2009 was likely caused by the transshipment of catch from one vessel to other vessel landed in Pekalongan. The purse seine catches from the Makassar Strait landed in Pekalongan from 2004-2011 were dominated by Decapturus russeli (44.7\%), Sardinella lemuru $(28.7 \%)$, S. gibbosa (6.9\%), and other fish species (each less than $7.0 \%$ ).

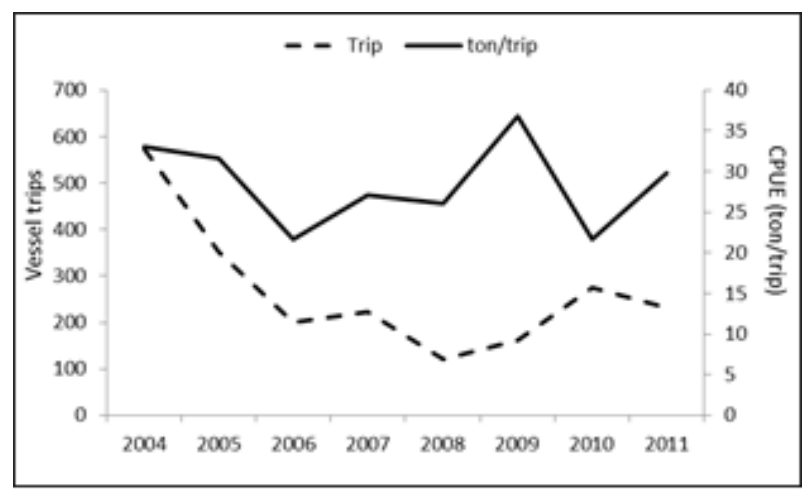

Figure 4. Number of trips and catch per trip based on purse seine vessel in Pekalongan.

\section{Purse Seine Vessels Based at Tegal Coastal Fishing Port}

The number of trips and catches per trip declined from 2004-2006, and then increased in the subsequent years (Figure 5). The dominant species caught by purse seine landed in Tegal comprised of Decapturus sp., Sardinella Gibbosa, Selar Crumenophtalmus, Rastrelliger sp. and Sardinella lemuru. Other species such as Euthynnus affinis, Scomberomorus and Bramidae were less than $10 \%$ of the total catch.

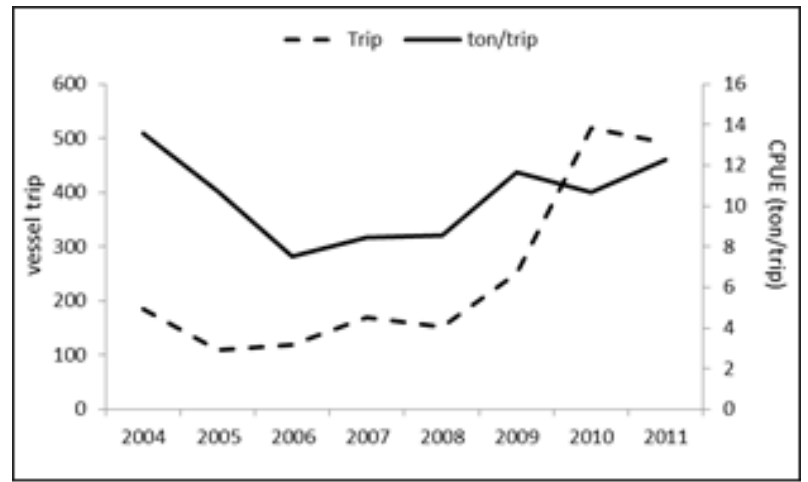

Figure 5. Number of trips and catch rate of purse seine that operated in Makassar Strait based at Tegal coastal fishing port.

\section{Purse Seine Fishing Based in Northern Java Ports (Juwana Coastal Fishing Port)}

The number of trips by large purse seiners increased from 504 trips in 2004 to 2,355 trips 2011, but the catch rate decreased from 25 ton/trip in 2004 to 10 ton/trip in 2011 (Figure 6). The catch was dominated by Decapterus sp. (about $54 \%$ of the total catch), with Sardinella lemuru, Rastrelliger sp, Sardinella Gibbosa and Selar Crumenophtalmus around $10 \%$.

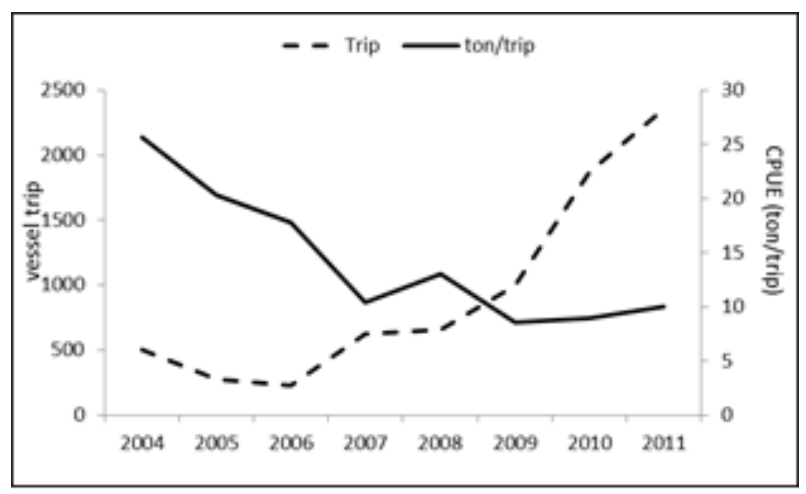

Figure 6. Number of trips and catch rate of purse seiners based at Juwana Coastal Fishing Port.

\section{Maximum Sustainable Yield}

Total catches of small pelagic by purse seine from Java and operating in the Makassar Strait, eastern of Borneo, decreased by more than $32 \%$ per year between 2004 and 2006, but then increased up to 37,755 tons in 2011. In the year 2004-2006 the catches largely were landed in Pekalongan. In contrast, higher catches were landed in Juwana than in Pekalongan and Tegal from 2008-2011 (Figure 7).

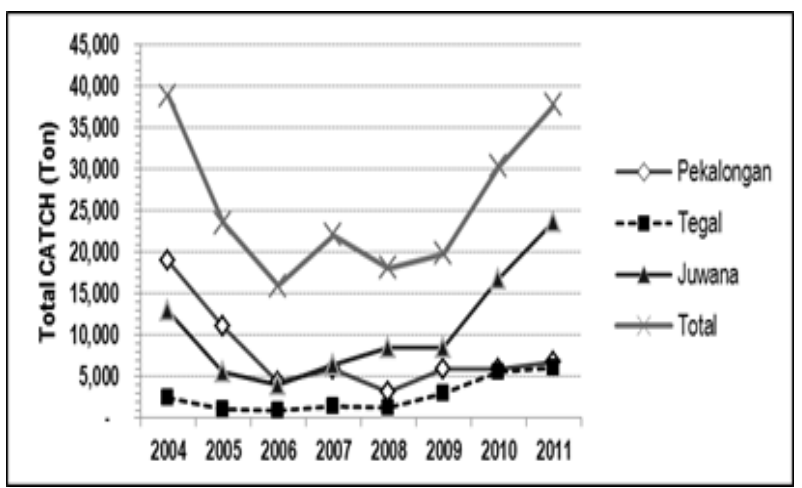

Figure 7. Annual catch of purse sein and operated in the Makassar Strait. 
The number of purse seine trips from Java tends to decrease between 2004 and 2006, but then increased in the subsequent years. The purse seine vessels from Juwana have higher number of trips, reached up to 2,355 trips in 2011. Unlike the number of trips by purse seine from Tegal, the number of trips by purse seine based at Pekalongan decreased. The number of trips by vessels from
Pekalongan and Tegal ranged between 110-574 trips (Figure 8).

There is a negative relationship between catch rate and efforts of the entire purse seine vessels operating in the Makassar Strait with coefficients of determination $\mathrm{R}^{2}$ equal to 0.8507 (Schaefer model) and 0.9181 (Fox model) (Figure 9).

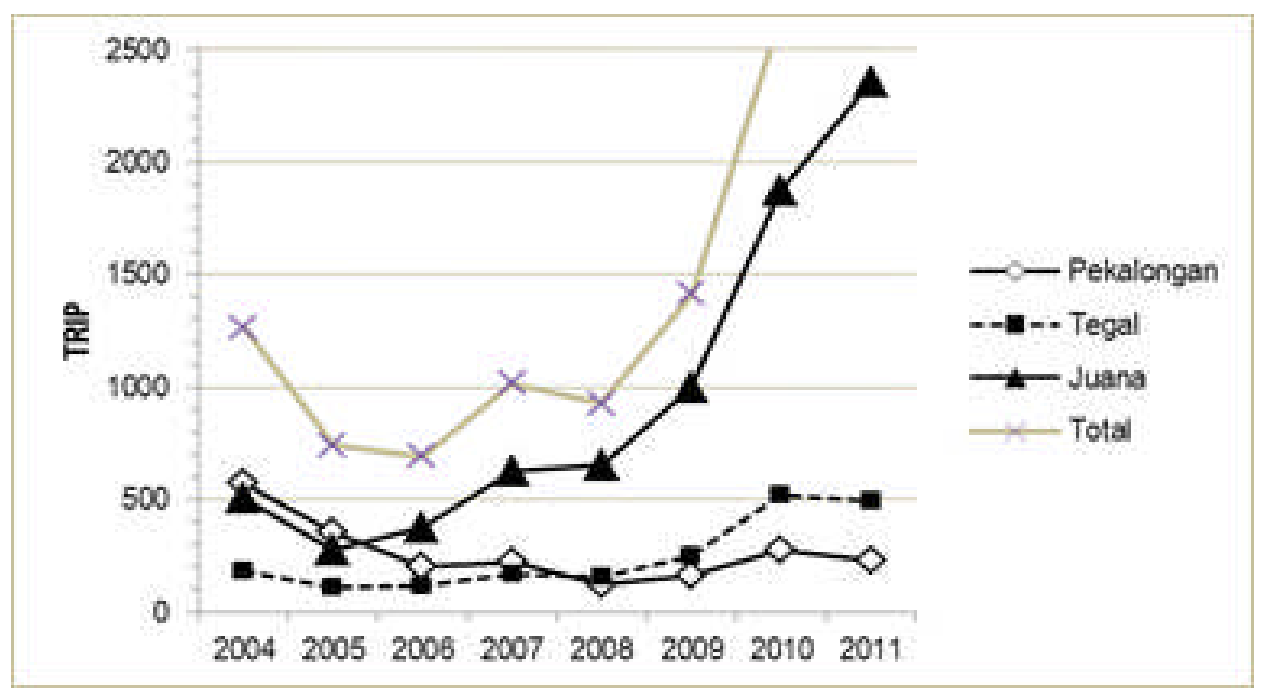

Figure 8.Number of purse seine trips operating in the Makassar Strait.

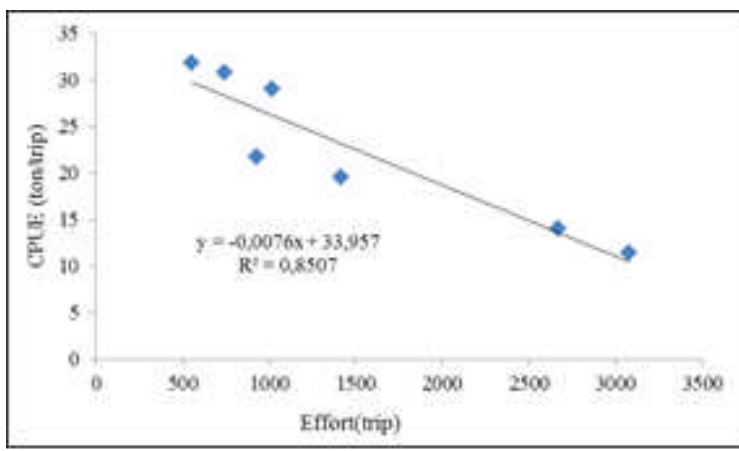

Schaefer Model

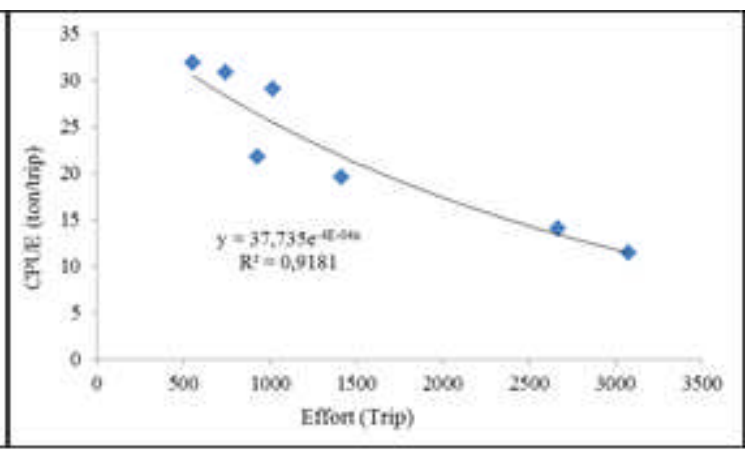

Fox Model

Figure 9. Relations betwen effort (trips) and CPUE (ton/trip) of purse seine operated in the Makassar Strait, using Schaefer Model and Fox Models.

The MSY and optimum effort were estimated using both models, i.e. MSY of 37,930 tons and optimum effort 2,234 purse seine trips (Schaefer model) and MSY of 34,705 tons and optimum effort of 2,500 purse seine trips (Fox model) (Figure 10). The catch rate of purse seine operating in the Makassar Strait largely decreased from 30.83 tons/trip in 2004 to 12.27 tons/ trip in 2011(Figure 11). 


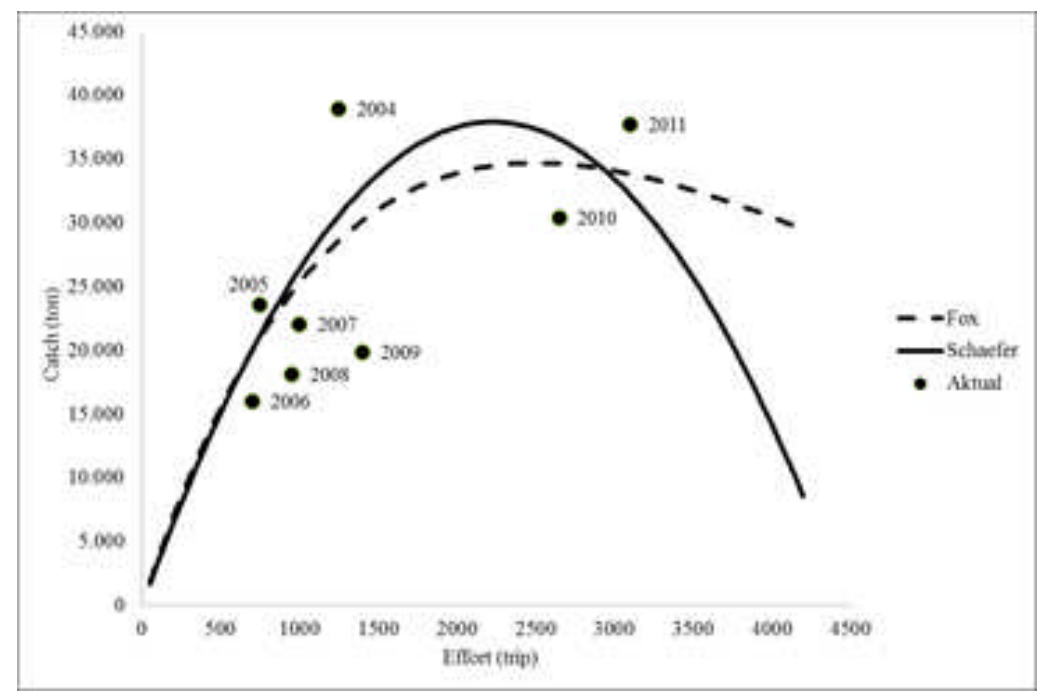

Figure 10. Relationship betwen effort and catch (ton) of purse seine operated in the Makassar Strait.

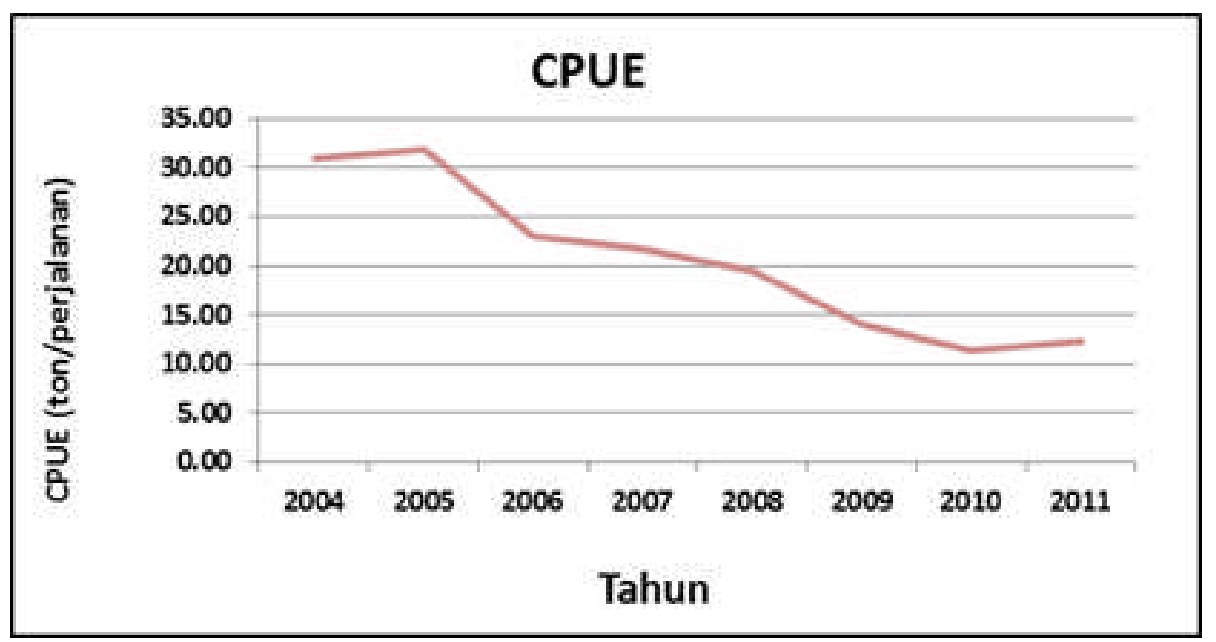

Figure 11. Annual CPUE (ton/trip) from 2004-2011 of purse seine operated in the Makassar Strait.

\section{Discussion}

Since trawl operation had been banned in 1980 in the Java Sea, the pelagic fish has become the main fish resources caught in the Java Sea, and purse seine has been used among the other fishing gears (Potier \& Sadhotomo 2003). Purse seine fishing operations occurred in the Java Sea between 1973 and 1982, then were more concentrated in the waters of Masalembo, Matasiri, and Kangean from 1983-1985, and then has expanded to the Makassar Strait and the South China Sea since 1986 (Potier \& Petit, 2003). Prior to 1992, only one fishing area was selected within a trip, but then after being equipped by a radio and other navigation tools, the one-way trip can operate in more than one fishing area. Based on fishing experiences from 1985 to 1992, fishing operations between January and April were concentrated in the waters of the Makassar Strait, from May-June in the
South China Sea, from August-September in the North of Java approaching the landing area, and from October - December in the waters of Masalembo, Matasiri and Kangean (Potier \& Sadhotomo, 2003). According to Sadhotomo \& Potier (2003), the bigger size of fish were found in the Eastern waters. The annual recruitment primarily occurs in June-August. Atmaja (1999) stated that it was more difficult for fishers to find the fish school, and the fish were only stayed in a fishing ground in a short time. The number of fishing days increased to around 50-80 days.

Figure 3 shows that Makassar Strait is considered to be the main fishing ground, which indicated by the higher percentage in 2009-2010. This condition is likely as a result of the decline in the number of fish stocks in the Java Sea, so that the fishing activities shifted to the Makassar Strait. 
The number of active vessels based at Juwana fishing Port has similar pattern as in Tegal fishing port, but relatively different with that in Pekalongan fishing port. This is likely due to the change or exchange of the landing area for the purse seine vessels, among the three landing areas.

The number of trips by large purse seiners increased between 2004 and 2011, but this was followed by the decrease in the catch rate. The decrease trend in the catch rate may indicate that overfishing is occurring in Makassar Strait.

The estimated MSY and optimum effort using Schaefer and Fox models indicated that the production and purse seine fishing effort in 2011, amounted of 37,755 tons and 3,078 trips respectively, are already exceeding the value of the MSY and optimum effort.

According to Sadhotomo \& Atmaja (2012), the surplus production analysis conducted on the purse seine fishery data based at Pekalongan and Juwana fishing ports, operating in the Makassar Strait, revealed some changes in the MSY values. Biomass increased from 55,000 tons in 1976-1981 to 180,000 tons in 1984-1990 and increased again to 284,000 tons in 1991-1998, whereas in 1999-2004 itdecreased to 204,000 tons. The analysis only used data from Pekalongan for the period of 1976-1981, due to low number of purse seine used in Juwana, while in the period of 1984-1990, the analysis used data from Pekalongan and Juwana fishing ports.

\section{CONCLUSION}

The large decreasing trend in the catch rate of purse seine fishery operating in the Makassar Strait from 2004 to 2011 may indicate that overfishing is occurring in the fishery. The MSY and optimum effort were estimated using Surplus Production model to be in the range of 34,705-37,930 tons and 2,234-2,500 trips, respectively. Therefore, the production and effort of purse seine in 2011, amounted of 37,755 tons and 3,078 trips respectively, are already exceeding the value of the MSY and optimum effort. In order to rebuild the small pelagic fish stock, the effort level need to be limited between 2,234-2,500 purse seine trips.

\section{ACKNOWLEDGEMENTS}

This paper is a contribution of the research activities "Fisheries and and Fish Stock Assessment of Small pelagic in Fisheries manageman Area (FMA) 713" at the Research Center for Fisheries Management and Conservation - Jakarta. We also would like to thanks stakeholders pelagic fisheries in the waters of the Java Sea for their contribution in providing information regarding the small pelagic fishery.

\section{REFERENCES}

Atmaja, S.B. (1999). (In Indonesian). Geographical Variation of Scads, Decapterus spp in the South of Sunda Shelf. J.Lit. Perik. Ind. 5 (3), 63-71.

Atmaja, S.B., Sadhotommo, B., \& Nugroho, D. (2011). (In Indonesian). Overfising in the semi-industry purse seine fishery in the Java sea and its management implication. J. Bijak. Perikan. Ind. $3(1), 51-60$.

Fox, W.W. (1970). An Exponensial Surplus-Yield Model for Optimizing Exploited Fish Population.Trans.Amer.Fish.Soc., No.1 (1970): 80-88.

Fujita, R. (2008). Individual Fishing Quotas. A WinWin Tool for Fisheries and Fishermen. An interview with our Expert Rod Fujita. www.edf.org/article.cfm.

Hartati, S.T., Triharyuni, S., Suwarso, Anggawangsa, R.F., Kasim, K., Hufiadi, Purwoko,R.M., Zamroni,A., Wujdi, A., \& Yunita, O. (2012). (In Indonesian). Fisheries and Fish Stock Assessment of Small pelagic in Fisheries manageman Area (FMA) 713. Technical Report. Center for Fisheries Research and Development.

Pauly, D. (1984). Some Simple Methods for the Assessment of Tropical Fish Stock (pp.52). FAO Rome.

Potier, M., \& Petit, D. (2003). Fishing strategies and tactics in the javanese seiners fisheries. Biology, Dynamics, Exploitation of the Small Pelagic Fishes in the Java Sea. The 2 nd Edition. Marine And Fisheries Research Project. The Agency for Marine And Fisheries Research.71-184.

Potier, M., \& Sadhotomo, B. (2003). Exploitation of the large and medium seiners fisheries. Biology, Dynamics, Exploitation of the Small Pelagic Fishes in the Java Sea. The 2 nd Edition. Marine And Fisheries Research Project. The Agency for Marine And Fisheries Research: 195-214.

Purwanto. (2011). (In Indonesian). Development, growth limit and optimation of the Indonesian marine fisheries potency. (p. 49). Research Center for Fisheries Management and Conservation. Agency for Marine and Fisheries Reseach and Development. 
Sadhotomo, B., \& Potier, M. (2003). Exploratory scheme for the recruitment and migration of the main pelagic spesies. Boilogy, Dynamics, Exploitation of the Small Pelagic Fishes in the Java Sea. The 2 nd Edition. Marine And Fisheries Research Project. The Agency for Marine And Fisheries Research: 155-168.

Sadhotomo, B., \& Atmaja, S.B. (2012). (In Indonesian). Synthesis of small pelagic fish stock assessment in the Java sea. J.Lit. Perik. Ind. 18(4), 221-231.
Suwarso, Haryati, T., \& Zamroni, A. (2012). (In Indonesian). Study on potency,abundan distribution and biology of small pelagic fish in the FMA 713 (Makassar strait-Flores sea-Bone bay) and FMA 714 (Banda sea-Tolo bay). Technical Report. Reseach Institute for Marine Fisheries, Jakarta. 